\title{
Entrustable Professional Activities for Community Medicine: Integrating Medical Undergraduate Courses and Primary Health Care
}

\author{
Ieda Francischetti1,2*, José Bitu Moreno', Ylva Holzhausen², Harm Peters² \\ ${ }^{1}$ Undergraduate and Postgraduate Programs, Marília Medical School, Marília, Brazil \\ ${ }^{2}$ The Dieter Scheffner Center for Medical Education and Educational Research, Charité-Universitätsmedizin Berlin, Berlin, \\ Germany \\ Email:`iedafster@googlemail.com,jbmorenoster@googlemail.com,ylva.holzhausen@charite.de,harm.peters@charite.de
}

How to cite this paper: Francischetti, I., Moreno, J. B., Holzhausen, Y., \& Peters, H. (2020). Entrustable Professional Activities for Community Medicine: Integrating Medical Undergraduate Courses and Primary Health Care. Creative Education, 11, 86-104.

https://doi.org/10.4236/ce.2020.112007

Received: December 28, 2019

Accepted: February 14, 2020

Published: February 17, 2020

Copyright $\odot 2020$ by author(s) and Scientific Research Publishing Inc. This work is licensed under the Creative Commons Attribution International License (CC BY 4.0).

http://creativecommons.org/licenses/by/4.0/

(c) (i) Open Access

\begin{abstract}
Community medicine represents a far-reaching field for the advance of health care, with impact on people's quality of life and health needs. Health promotion, disease prevention, recovery and rehabilitation have to be incorporated satisfactorily into medical education. The search for a pedagogical tool to fulfill the medical curriculum through actions of community medicine care led us to outline 11 Entrustable Professional Activities (EPAs) for community medicine. The study was carried out at a public Medical School in Brazil that has a Competency-Based Curriculum (CBC). Fifteen teachers with expertise in community medicine analyzed the resulting EPAs. The EPAs were distributed in three domain areas: care needs of the individual, family and community in Primary Health Care. The teachers answered a total of 13 open questions in a two-round Delphi study. The discourses were submitted to thematic content analysis. Three discourse categories were found about the outlined EPAs: curriculum management and social needs, curriculum management and service integration, and curriculum management and actors. The understanding of the EPAs as a curriculum management tool was relevant, as well as their interface with health care and learning development. The consulted teachers agreed with the designed EPAs and that they are adequate for the first two years of the studied medical course in their Brazilian context. Therefore, it was concluded that the community medicine EPAs are appropriate for the new medical profile, especially in countries with social exclusion, and are a very good tool to promote integrality of care and humanism. This study can facilitate the implementation of a CBC in community medicine and
\end{abstract}


assist in overcoming its challenges through the adoption of the designed EPAs.

\section{Keywords}

Primary Health Care, Community Medicine, Entrustable Professional Activities, Medical Education, Clinical Competence

\section{Introduction}

Competency-Based Medical Education (CBME) has become largely accepted in medical undergraduate courses, mainly due to its practical approach, which can foster a more responsive type of care.

For economic and social reasons, the most expected medical profile around the globe is that of an interactive, generalist professional who is able to meet the population's health demands with effective, integral and humanistic care, and who has an epidemiological and social perception. The World Health Organization (WHO) has requested that formative health agents should become more committed to their social realities. Community medicine represents the key approach to meet people's real needs and act in health surveillance.

The search for a better way to implement the medical curriculum in community medicine was mobilized by the demand for offering a qualified and praxis-focused undergraduate medical course based on medical competence. The implementation and assessment of what is called "competence" are complex processes and, to preserve the potentiality of this construct, extended integration with the real context is required (Frank et al., 2010; Lima, 2005).

It has been described that Entrustable Professional Activities (EPAs) are a very good instrument to convert CBME into daily medical practice. Thus, this study proposes a description of EPAs to mediate the accomplishment of CBME, so that it meets individual, family and community care needs in primary health care (ten Cate, \& Scheele, 2007; Chen, van den Broek, \& ten Cate, 2015; ten Cate, 2005). As qualified student education and satisfactory health care are important objectives of health actions, we present, in this article, competencies and EPA areas for the medical curriculum. We describe 11 EPAs for the first two years of a Brazilian medical school's competency-based curriculum that is strongly grounded on health surveillance and community medicine (Lei ${ }^{\circ} 8.080$ de 19 de setembro de 1990; Resolução CNE/CES n 3 de junho de 2014; Brasil, 2008). In addition, the analysis of the expert teachers' opinion about the described EPAs and their implications for curriculum management helps us to suggest that the use of this tool is a powerful strategy to the implementation of CBME for community medicine.

Community medicine

Since the Alma-Ata Conference (World Health Organization, 1978), WHO 
has emphasized the relevance of primary health care, interdisciplinary and intersectoral actions to improve quality of life, integration of health services, intersectoral policies, and the empowerment of people and the community.

Thus, community medicine represents a wide space for the advance of medicine. Not only public health, but also the relationship among people who live in the community and all the environmental, social, cultural, economic, biological and familial facets have an impact on people's quality of life and health needs. Therefore, a holistic and humanistic view is needed to decode the constituents of the health problem and to offer the right support (promotion, prevention, recovery or rehabilitation). This configures an amplified clinical approach supported by public health knowledge that offers an answer tailored to each person within his or her community. Naturally, it is a collective construction of care involving the local public health policy (Park, 2005; Kumar, 2005; Horton, 2013).

Health promotion and disease prevention have been shown to effectively enable people to lead a social and economic productive life. While this combination of actions relieves costs and demands for high technology, avoiding illness development or breaking its cycle, it unblocks the system with agile decentralized care (Muller et al., 2010; Jones, Higgs, Angelis, \& Prideaux, 2001; World Health Organization, 1996, 2000, 2008; Health Canada, 2002).

These aspects have been incorporated into medical education. Thus, over the last decades, Canada, United Kingdom, Australia, USA, the Netherlands, Scotland, India, Indonesia, and Thailand have made efforts to align health and education policies and to include their medical students in primary health care. The strengthening of the family doctor policy is very important, and successful teamwork including medical students has also been reported in Portugal, Brazil, Spain, and Sweden, with good care outcomes (Hunt, Bonham, \& Jones, 2011; Soler, Carelli, Lionis, \& Yaman, 2007; Dornan, Littlewood, Margolis, Scherpbier, Spencer, \& Ypinazar, 2006; Brekke et al., 2013; Neto, Antunes, \& Oliveira, 2019; Martin-Moreno, Alonso, Claveria, Gorgoio, \& Peiró, 2019; Costa, Pedro, \& Magalhães, 2014; González \& Almeida, 2010; Kishore, 2016; Raghav, Kumar, \& Bhardwaj, 2016; Kelly et al., 2019).

CBME's commitment to qualified care outcomes is expressed by its active pedagogical method, integrated contents and community-centered approach. Some medical schools have been offering a Community-Based Curriculum in order to adjust the competencies that must be developed to the community services (Soler, Carelli, Lionis, \& Yaman, 2007; Dornan et al., 2006; Brekke et al., 2013; González \& Almeida, 2010).

In the Brazilian context, Municipal Health Departments have had an active participation in the development of health courses' curricula. Through this partnership, students and teachers are inserted in municipal health services and Health Department professionals participate in the construction of the educational units of Brazilian courses. This confluence of goals aims to better service the National Health System, which works in three different health service levels, 
named according to their complexity degrees: primary care (basic care), secondary care, and tertiary care.

Primary care centers on community medicine driven by a Family Health Strategy based on health surveillance principles. The main tasks are to identify personal, family and collective necessities in order to manage health work and to develop health surveillance (promotion, prevention, treatment, recovery and rehabilitation) (Lei n 8.080 de 19 de setembro de 1990; Brasil, 2008, Faculdade de Medicina de Marília, 2014). Secondary care focuses on outpatient care and low complexity hospital care, while tertiary care refers to hospitals that offer high complexity health care (Lei $n^{\circ} 8.080$ de 19 de setembro de 1990; Brasil, 2008).

For more than 15 years, the Brazilian CBME has strived to meet the needs and demands of the national society, offering an integrated, critical and ethical practice based on teamwork and continued learning. It is oriented by the belief that "the development of activities in real scenarios implies both learning and effective and integral care for the person" (Faculdade de Medicina de Marília, 2014: p. 34). In many places, its guiding conception is that of health surveillance, providing promotion, prevention, recovery, and rehabilitation measures in order to offer a better quality of life to the patient (World Health Organization, 2009, 2010, 2018; Chaturverdi, 2015; Seyednozadi, Shahraki, \& Moghaddam, 2018; Gopalakrishnan \& Kumar, 2015). Therefore, we can see CBME's vocation for promoting a new health professional profile (Resolução CNE/CES n ${ }^{\circ} 3$ de junho de 2014).

In a review study in medical education about global health competencies, Battat et al. (2010) found common competencies in 33\% of the articles; another finding was that the drive "to understand primary care" was always present (Battat et al., 2010). For their part, Tamblyn et al., in a cohort comparison study, showed that a transition to a community-oriented problem-based learning curriculum was associated with significant improvements, not only in preventive care and continuity of care, but also in diagnostic performance indicators (Tamblyn et al., 2005). However, this movement must be monitored, assessed, and assured. Only then will it be able to ensure student's integration into the reality of the local health service (Faculdade de Medicina de Marília, 2014; World Health Organization, 2009; Seyednozadi, Shahraki, \& Moghaddam, 2018; Gopalakrishnan \& Kumar, 2015).

\section{Competency-based curriculum (CBC): A social development device}

To discuss this point, it is necessary to approach some concepts. Professional competence curricula appeared more than 20 years ago in postgraduate health programs in order to provide professional training with the articulated use of the knowledge, skills, and attitudes necessary to satisfactorily meet the health demands of the population (Frank et al., 2010; Smith, 1999; Harden, 2007).

CBME has a conceptual character based on the delivery of results, represented by the outcome of health work, the consequences of adopting this type of education, and its professional actions, interpreted through areas of competence. 
Several elements can contribute to the qualification of a competent professional. Nevertheless, it is not possible to control the administration of the multiple, internal and interpersonal factors involving a complex health situation, and this is rarely trained in its entirety (Lima, 2005; Harden, 2007; Epstein \& Hundert, 2002; Hodges \& Lingard, 2012).

Professional competence has different meanings according to place, goal and local policies. In Brazil, the strong and necessary link between health care policy and health professional education contributes to the development of professional competence in the world of work. This calls for the adaptation of the curriculum to the construction of real-life scenarios, which allows the transit of cognitive, affective, ethical, psychomotor, and socioenvironmental elements, and enables the development of care practice with responsibility and commitment to others (Resolução CNE/CES n 3 de junho de 2014; Faculdade de Medicina de Marília, 2014; Epstein \& Hundert, 2002; Hodges \& Lingard, 2012).

However, several authors have warned about the risks posed by the management of competency-based curricula. Their real capacity to foster a professional education that is able to respond to the social mission delegated to it is questionable (Harden, 2007; Brightwell \& Grant, 2013; Touchie \& ten Cate, 2016; Carraccio, Wolfsthal, Englander, Ferentz, \& Martin, 2002; Gonczi, 2013; Schuwirth \& Van der Vleuten, 2011). Reductionism related to conceptual, implementation and evaluation issues is mentioned in the literature and calls attention to the harmful tendency of these aspects overlapping the humanistic and relational nature of the health professional practices, by means of the adoption of behavioral training, with a theory-practice gap and fragmentation of evaluation. This results in the loss of the integrality perspective inherent in health care (Brightwell \& Grant, 2013; Touchie \& ten Cate, 2016; Carraccio, Wolfsthal, Englander, Ferentz, \& Martin, 2002; Gonczi, 2013; Schuwirth \& Van der Vleuten, 2011).

Despite possible setbacks, the prioritization of the work context allows for the emergence of important aspects, such as the assessment of practice, the opportunity to bond with the team and patients, the chance to integrate clinical knowledge and clinical skills, and the development of communication skills and clinical reasoning, not to mention the experience gained through individual tasks (ten Cate, Snell, \& Carraccio, 2010). Frank et al. (2010) emphasize the multidimensional, contextual and dynamic conformation of professional competence and its developmental nature, as it offers to the student/professional opportunities for lifelong learning (Frank et al., 2010). Furthermore, according to Epstein and Hundert, "good assessment in itself is a form of learning and can provide guidance and support to address learning needs" (Epstein \& Hundert, 2002: p. 229).

Thus, several studies have shown that it is possible to insert the development of the health professionals' competence in the place where they work, provided that there is an assessment process that takes into account the various actors and 
the reality of the health department as producers of quality of life (World Health Organization, 2008; ten Cate, Snell, \& Carraccio, 2010).

The emergence and already widespread use of Entrustable Professional Activities (EPAs), not only in postgraduate education but also in undergraduate medical education, represent a great contribution to fulfill this goal. EPAs are an instrument that can build a bridge between CBME and medical practice in real-life scenarios, strengthening the assessment process (ten Cate, 2018; Holzhausen, Maaz, Renz, Bosch, \& Peters, 2019; Peters, Holzhausen, Boscardin, ten Cate, \& Chen, 2017; ten Cate, Graafmansa, Posthumusa, Welinkd, \& van Dijke, 2018).

\section{EPAs and community medicine}

EPAs are activities that compose the professional medical practice of physicians in their daily work and enable them to transpose the curricular competence conception to actions in health work processes. The medical student acts in care production, putting EPAs into practice while immersed in the health system, working in teams, with the patient and under teachers' supervision (ten Cate, Snell, \& Carraccio, 2010; ten Cate, 2018).

According to the literature, the assessment of student's performance in CBME should enable the observation of students working in practical situations that combine knowledge, attitudes and skills, and performing practices that are part of the corpus of professional practice (Hodges \& Lingard, 2012; ten Cate, Graafmansa, Posthumusa, Welinkd, \& van Dijke, 2018; ten Cate, 2013). The use of EPAs for this purpose has been largely suggested and demonstrated (ten Cate, \& Scheele, 2007; Chen, van den Broek, \& ten Cate, 2015; ten Cate, 2005; ten Cate, Graafmansa, Posthumusa, Welinkd, \& van Dijke, 2018; ten Cate, 2013; Carraccio \& Burke, 2010).

The adoption of EPAs is able to reflect the student's current evolution. In addition, it allows the performance of formative evaluation and the exercise of a summative and supervised approach, not only in the simulated scenario but, and especially, in the real world (ten Cate, 2006; Sklar, 2016).

The teacher's role is very relevant here. As a supervisor with expertise in the praxis context, the teacher is able to offer productive and reliable feedback to the student, strengthening their professional development. Therefore, it is very important that teachers are qualified, as they must have the capacity to encourage students and to create a mutual trust relationship based on empathy. Attitudinal, technical and ethical aspects work together; thus, skills, training, feelings, self-esteem, self-confidence, and supervisor's confidence enhance the EPAs' formative and evaluative capacity (ten Cate, Graafmansa, Posthumusa, Welinkd, \& van Dijke, 2018; ten Cate, 2013; Carraccio \& Burke, 2010; ten Cate \& Hoff, 2017). Through the EPA process, responsibility is also developed, as the student will be acting on behalf of the patient and has to be sure in order to anticipate risks or avoid the existing ones. The training provided by entrustment and supervision is a great contribution to the quality of training, and to patient's and health services' safety (Sklar, 2016; ten Cate \& Hoff, 2017). 
Based on this, the suitability of EPAs in the competency-based implementation of community medicine seems quite logical. It is expected, therefore, that the curriculum construction reflects its local reality and health policy, considering the community's and family's health needs (Faculdade de Medicina de Marília, 2014; Association of Family Medicine Residency Directors, 2019). Within this context, CBME must identify elements that provide subsidies for the performance of health surveillance (World Health Organization, 2010; Epstein, \& Hundert, 2002; Hodges \& Lingard, 2012; Association of Family Medicine Residency Directors, 2019).

Thus, this study aims to identify domain areas and describe their related EPAs, considering actions that could promote systematized practices supporting a good and appropriate medical education, based on the Brazilian reality and needs, and with multi-professional and academia-service integration. The study's reference model is the curriculum of a state medical school whose course lasts 6 years, adopted active learning methods 22 years ago, and has had a $\mathrm{CBC}$ for 15 years. The present work investigates the first two years of this course. In the current curriculum, half of the activities occur in primary care services (Neto, Antunes, \& Oliveira, 2019; ten Cate, Graafmansa, Posthumusa, Welinkd, \& van Dijke, 2018; Association of Family Medicine Residency Directors, 2019).

\section{Material and Methods}

This exploratory-descriptive study aimed to describe and analyze the qualitative contributions of a Delphi consensus study carried out to define community medicine EPAs for a medical curriculum based on the Brazilian reality.

The study was conducted at the Marilia Medical School (Faculdade de Medicina de Marília-FAMEMA), a state-run medical school located in the State of São Paulo, Brazil, which adopted problem-based learning 22 years ago and has a CBC (Faculdade de Medicina de Marília, 2014).

The FAMEMA complex serves 62 municipalities and 2 million inhabitants. The medical course lasts 6 years, with a total of 11,079 hours. The first two years have $45 \%$ of their activities in primary care (1380 hours), located in the community by the Family Health Strategy (Faculdade de Medicina de Marília, 2014).

The study was approved by the Brazilian Ethics and Research Committee on September 12, 2019 (no. 3.571.405), and by the National Health Council (466/2012), Operating Rule 001/2013.

The first stage of the study was the description of 11 EPAs for community medicine for the first two years of medical school. The produced material was submitted to the appreciation of a panel of specialists, according to the Delphi technique (Holzhausen, Maaz, Renz, Bosch, \& Peters, 2019; Lynn, 1986; Alexandre \& Coluci, 2011; Scarparo et al., 2012). The panelists were teachers with content expertise in community medicine: six nurses and nine physicians.

The definition of EPA domains and initial EPA descriptions were performed 
by the authors of the study, physicians with large experience in medical education and community health care. The study was developed in two phases: in the first one, the authors followed the description steps for EPA design recommended by ten Cate (ten Cate, 2018), and prepared the material, ensuring there was correspondence between the local curriculum competence areas and the EPA domain areas for community medicine. In this phase, 11 core EPAs for community medicine and their respective domain areas were described.

In the second phase, the Delphi study was conducted. It was carried out in two rounds. In each round, the panelists were asked to express their perceptions and opinions on the concept and content of the core EPAs for community medicine by answering in writing, without word limit, 13 open questions (qualitative approach). In addition, the panelists rated quantitatively their consent on the elaborated content of the 11 core EPAs with a Likert scale with four-point ordinal model (Holzhausen, Maaz, Renz, Bosch, \& Peters, 2019), which is the scope an upcoming article.

The open questions resulted in discursive contributions to different aspects of the core EPAs for community medicine. These discourses were analyzed qualitatively according to the thematic modality of content analysis, as structured by Bardin, who proposes content analysis in three phases: pre-analysis, material exploration and treatment of results, inference and interpretation (Bardin, 2016; Campos, 2004).

The discourses were transcribed and identified with letters " $M$ " or " $N$ " for medical professionals or nurses, respectively, and with Arabic numerals according to the questionnaire reception order.

The quantitative study will be the goal of a future paper.

\section{Open Questions}

The 13 panelists' discursive answers for five researched points were submitted to a thematic content analysis.

The teachers answered two general questions about the designed EPAs. The first question was about the capacity of the three EPA domains to mediate the medical students' development in light of the expected professional practice approached in the curricular section corresponding to the end of the second year of the course. The second question was related to the EPAs' capacity to subsidize the development of the four competence areas present in FAMEMA's curriculum for the same period of the course (questions I and II). The other questions approached the EPAs presented in Figure 1. Question III was asked five times, one to each EPA of the domain "Integrality of care for the health needs of the individual in all phases of the life cycle". Question IV was asked three times, one to each EPA of the domain "Integrality of care for the health needs of the family". Question V was also asked three times, one to each EPA described in the domain "Integrality of care for the health needs of the community", as follows:

1) Do the described 11 Core EPAs distributed in three EPA domains represent 
the professional activities of the medical student at the end of the second year of the medical course?

2) Can competencies from the four competence areas of FAMEMA's medical curriculum be found in all three EPA domain areas that represent the professional activities of the medical student at the end of the second year of the medical course?

3) Do you agree with the description, conditions and implications of the entrustment decisions for each of the five EPAs of the domain "Integrality of care for the health needs of the individual in all phases of the life cycle"?

4) Do you agree with the description, conditions and implications of the entrustment decisions for each of the three EPAs of the domain "Integrality of care for the health needs of the family"?

5) Do you agree with the description, conditions and implications of the entrustment decisions for each of the three EPAs of the domain "Integrality of care for the health needs of the community"?

\section{Results}

\section{Community medicine EPAs and EPA domain areas}

In accordance with WHO's orientation (World Health Organization, 2009, 2010, 2018), with the Brazilian public health policy (Lei n ${ }^{\circ} 8.080$ de 19 de setembro de 1990; Resolução CNE/CES n 3 de junho de 2014; Brasil, 2008), and with FAMEMA's medical curriculum (Faculdade de Medicina de Marília, 2014), the panelists, through the Delphi study, agreed on the definition of three EPA domain areas for community medicine for the first and second years of the medical course. The domains were oriented towards integrality of health care to meet people's health needs in three dimensions aligned with community medicine assumptions:

1) Integrality of care for the health needs of the individual in all phases of the life cycle,

2) Integrality of care for the health needs of the family, and

3) Integrality of care for the health needs of the community.

Eleven Core EPAs were consensually devised for the three EPA domain areas and were distributed according to Figure 1.

With the analysis of the obtained discourses in the first round of the Delphi study, it was found that $26.6 \%$ of the panelists had not recorded discursive contributions. Nevertheless, it was found that the contributions largely explained the panelists' understanding of the operationalization context of the EPAs.

\section{Content analysis}

According to Figure 2, three discourse categories emerged, representing the consulted teachers' comprehension of the curriculum management capability of the EPAs and their interface with health care and learning processes. The categories were curriculum management and social needs, curriculum management and service integration, and curriculum management and actors. 
Core EPAs for 3 EPAs domains for the first and second medical course years

1. Integrality of care for health needs of the individual in all phases of the life cycle

1.1 First consultation to diagnose the health needs of an individual

1.2 Development and management of the Individual Therapeutic Project (ITP)

1.3 Follow-up consultation on individual health needs

1.4 Perform of procedures for individual care in health surveillance

1.5 Management of health care support strategies

2. Integrality of care for health needs of the family

2.1 First consultation to diagnose of family health needs

2.2 Development and management of the family health needs

2.3 Follow-up consultation on family health needs

3. Integrality of care for health needs of the community

3.1 Diagnose the health needs in the community

3.2 Development and management of the Health Project in the Territory (HPT)

3.3 Follow-up of the Health Project in the Territory (HPT)

Source: the authors

Figure 1. The three EPA domain areas and their respective core EPAs.

\begin{tabular}{|l|l|}
\hline Speech categories & Definitions \\
\hline Curriculum management and social needs & $\begin{array}{l}\text { The capability of the EPAs to effective the } \\
\text { prescript curriculum and their acceptance to } \\
\text { attend social needs }\end{array}$ \\
\hline $\begin{array}{l}\text { Curriculum management and service } \\
\text { integration }\end{array}$ & $\begin{array}{l}\text { The active curriculum role to foment service, } \\
\text { academy and community integration for } \\
\text { healthcare integrality }\end{array}$ \\
\hline Curriculum management and actors & $\begin{array}{l}\text { This category told about the commitment of } \\
\text { teacher-student partnership to develop } \\
\text { community medicine EPAs in the service }\end{array}$ \\
\hline
\end{tabular}

Source: the authors

Figure 2. Discourse categories and definitions.

\section{Results and Discussion}

\section{1) Curriculum management and social needs}

This category involved the capability of the EPAs to effectuate the prescribed curriculum and the recognition of their adequacy to meet people's social needs, which can be seen in the following fragments:

The competencies are covered; they [EPAs] approach the person's safety and health, strengthening professional identity, management and values. (M4)

Considering that knowledge, skills and attitudes are quite clear, through EPA, the student can develop a diagnosis of the family's health needs. (N1)

From the discourses, it is clear that the described EPAs are adequate to conduct community health practices, and that the teachers are aware and motivated to explore their potential for meeting community needs:

I thought student's attributions are well described, but in the specifications, I think it would be interesting to add clinical-epidemiological reasoning, especially because our context is Brazil. (N6)

I agree. Maybe this could bring more health education actions and promote a joint work with community leaders. (N3) 
To think about adolescent health care according to the needs of the territory, as a priority action. The same applies to the issue of Domestic Violence. (M6)

These statements point to the necessary correspondence between the technical description of the EPAs as an instrument for practice, knowledge about the local reality, and the health needs of this community (Cecílio, 2009), so that care and learning are effective and meaningful. In this context, it is worth recalling the educational principle of irreducible commonplaces, which recognizes the interaction among the teacher, the learner, the content, and the context (Bretz, 2001). Meaningful learning occurs through integration, in a constructive way, of thinking, feeling, and acting, and can lead to human empowerment with commitment and responsibility (Bretz, 2001; Moreira, 2010).

\section{2) Curriculum management and service integration}

This category approached the curriculum's commitment to academia-service-community integration to foster health care integrality. It was seen as a challenge:

The Individual Therapeutic Project (ITP) involves the systematization of the work process and, in this context, it is necessary to synchronize the service with the actions, so that the student experiences the care process in practice. (N1)

The discussion about the visited families could include members of the service team and not only the supervising teacher, as the team often knows the family better. (M9)

The panelists expressed their comprehension of the potentiality of the proposed EPAs to mediate integrated health care. Integrality in health is: a fundamental principle of public health systems which guarantees to citizens the right to be assisted, from disease prevention to the most difficult treatment of a condition, not excluding any disease, prioritizing activities and preventive care services without prejudice. Integrality implies a healthcare and healthcare management that recognize the autonomy and cultural and social diversity of individuals and populations (Biblioteca Virtual de Saúde, 2019).

This understanding about EPAs points to their capacity for contributing to the management of micropolitics, bringing academia closer to the services' actors through the integrated teamwork approach. The goal of health care, in addition to providing integrated professional care, is to see the individual as a multifaceted being with their multiple determining factors (individual, familial, cultural, social, economic, educational, among others) (Santos et al., 2018).

Moreover, the panelists mentioned a very important aspect: intersectoral management to achieve academia-service cooperation.

I do not know if the service's manager is fully aware [of the importance of the partnership]. (M3) The local political factor always becomes a limiting factor. (M5)

According to Swanwick (2014), the meeting of public health and medical education is placed in a highly political and macro-political sphere, as it involves both the available structure for the best health care provided to the population 
and the training of future professionals to offer the best-expected health (Swanwick, 2014).

Therefore, it is a space of increasing accountability and regulation that must aim at security, efficiency, and intersectorality to ensure continuing care in all complexity levels and at the three care management levels: local, state, and federal. It can be concluded that "Intersectorality holds an important place in integrality, as primary health care focuses mainly on health promotion actions that directly affect the conditions and determinants of the health-disease process." (Santos et al., 2018: p. 1239)

In addition, some panelists understood that the EPAs for community medicine could strengthen the construction of integrality and intersectorality through social participation, including all the interested parties: academia, service, and community:

To investigate the development of management, the attempts to redefine the roles of professionals, the people, including them in the co-production of possible solutions and facilitating decision-making. (M4)

To be viable, there would need to be contacted with levels beyond the basic unit, such as the manager's planning team and the units' community councils, which, in many cases, never got off the ground. (M9)

The execution of community medicine EPAs requires the mobilization of the care team, which is formed by professionals with different backgrounds who need to learn about the situation and learn with each other in order to meet the health needs. Many aspects count, such as context factors, engagement, experiences, knowledge, commitment, confidence, technical support, among others (Eraut, 2011). The presence of reflection and encouragement is very important for personal development, judgment capability and decision-making (Eraut, 2011). The community's participation in meetings to process local demands and possibilities can multiply the service's capability for providing answers and students' learning process (Santos et al., 2018). The community profits in terms of citizenship, participation and quality of care.

\section{3) Curriculum management and actors}

This category approached the commitment of the teacher-student partnership to developing community medicine EPAs in the services. Some discourses mentioned the teacher's vigorous role and responsibility and considered that the EPAs motivate students and students' pair work is encouraging:

The teacher will be the cornerstone for this to happen; the student alone, starting from him or her alone, I find it more difficult and complicated. (M3)

This will require a change in the teacher's profile as well. (M3)

I believe that supervision should still be mandatory, and it is not up to the student to decide whether or not to supervise. (N2)

The teacher's role in EPAs is very important because it requires not only supervision but also a clinical insertion and teamwork interaction when building a trustful learning environment. According to Sklar (2016), these trust relation- 
ships must be developed over time between the faculty and their students (Sklar, 2016); we add that, in community medicine, the health team and the patients must have a comfortable and integrated relationship.

The idea is to recognize the important value of the faculty-learner supervisory relationship to the overall quality of care provided to patients in the educational environment. The EPA concept, with its emphasis on the learner's workplace assessment and entrustment for certain activities, reinforces the dual educational and quality-of-care aspects of a faculty-learner supervisory relationship (Sklar, 2016: p. 156).

The teacher as an evaluator must be engaged in and committed to students' assessment, guiding them towards a secure performance with trust and independence. According to the panelists whose discourses were quoted above, they need to recognize each other's strengths, limitations and values.

Other panelists expressed the idea that the EPAs may facilitate student's motivation and performance:

The student will be motivated. (N6)

I think the student, in this dual-visit model, feels safer and supportive. (M5)

The idea of interacting with reality and effective care is the goal of the medical profession. It is very motivating, for medical students, to rescue their professional identity (Swanwick, 2014). The described EPAs mediate ways to implement and integrate many different competencies in the workplace, with concrete and visible results and patient's feedback (Tamblyn et al., 2005).

It was shown that, when students learn in pairs, their motivation and interest are greater than when they learn individually. The pairs had a greater focus on the task, a better social behavior, trust, and cognitive learning. Their mutual help and assistance resulted in learning that is more active. In addition, supervision could have a longer duration and could be more effective (Brush, 1997).

\section{Conclusion}

This study shows that the group of community medicine specialists agreed with the 11 EPAs for community medicine described for the three domain areas: Integrality of care for the health needs of the individual in all phases of the life cycle, Integrality of care for the health needs of the family, and Integrality of care for the health needs of the community.

The specialists' perception corresponds to the view expressed in the literature review on global health conducted by Battat et al. (2010), which pointed to the need of preparing the future medical professionals to work in community medicine and primary health care with practical tasks since the first year of the medical course (Battat et al., 2010).

The focus on the individual, family and community can promote comprehensive health care in an integrated way, capable of meeting the social needs of the population with social inclusion and access to health care. Therefore, we concluded that the community medicine EPAs are appropriate for the new medical 
profile, especially in countries with social exclusion.

The discursive answers demonstrated the panelists' understanding of the EPAs as a curricular management tool capable of meeting the community's health needs, enabling teaching-service integration, promoting the integrality of care in actions related to micropolitics, and encouraging teacher and student engagement in the process of producing care and knowledge.

Furthermore, the panelists advocate the importance of including, in the community medicine EPAs, clinical-epidemiological reasoning, health education and local attention to the health territory needs, like, for example, the need to approach domestic violence.

The other two relevant points were the challenge of promoting intersectionality, which demands macropolitical actions and involves the public management of health, and the importance of the teacher's role as a clinical doctor, a supervisor, and as an encouraging support for health practices and for the quality of learning.

\section{Final Consideration}

We agree with Muller et al. (2010), when they argue that "looking forward to the next 100 years, our curricula must revolve around patients and their communities, as opposed to disciplines or the needs of the profession" (Muller et al., 2010: p. 308), and we consider that community medicine EPAs are a very good tool to promote integrality of care and humanism.

In addition, this study can facilitate the implementation of a CBC in community medicine and assist in overcoming its challenges.

\section{Funding}

Ieda Francischetti: grant 2018/26011-2, São Paulo Research Foundation (FAPESP).

\section{Conflicts of Interest}

The authors declare no conflicts of interest regarding the publication of this paper.

\section{References}

Alexandre, N. M. C., \& Coluci, M. Z. O. (2011). Validade de conteúdo nos processos de construção e adaptação de instrumentos de medidas. Ciência \& Saúde Coletiva, 16, 3061-3068.

http://www.scielo.br/scielo.php?script=sci arttext\&pid=S1413-81232011000800006\&ln $\mathrm{g}=\mathrm{en}$ https://doi.org/10.1590/S1413-81232011000800006

Association of Family Medicine Residency Directors (2019). Entrustable Professional Activities (EPAs). https://www.afmrd.org/page/epa

Bardin, L. (2016). Análise de conteúdo. São Paulo (SP): Edições.

Battat, R., Seidman, G., Chadi, N., Chanda, M. Y., Nehme, J., Hulme, J., Li, A., Faridi, N., \& Brewer, T. F. (2010). Global Health Competencies and Approaches in Medical Education: A Literature Review. BMC Medical Education, 10, 94. 
http://www.biomedcentral.com/1472-6920/10/94

https://doi.org/10.1186/1472-6920-10-94

Biblioteca Virtual de Saúde (BVS) (2019). Descritores em Saúde.

http://decs.bvs.br/cgi-bin/wxis1660.exe/decsserver/

Brasil (2008). Ministério da Saúde. Secretaria de Atenção à Saúde. Núcleo Técnico da Política Nacional de Humanização. HumanizaSUS: Documento base para gestores e trabalhadores do SUS/Ministério da Saúde, Secretaria de Atenção à Saúde, Núcleo Técnico da Política Nacional de Humanização (4rd ed., 72 p.). Brasília: Editora do Ministério da Saúde.

Brekke, M., Carelli, F., Zarbailov, N., Javashvili, G., Wilm, S., Timonen, M., \& Tandeter, H. (2013). Undergraduate Medical Education in General Practice/Family Medicine throughout Europe-A Descriptive Study. BMC Medical Education, 13, 157.

https://doi.org/10.1186/1472-6920-13-157

Bretz, S. L. (2001). Novak's Theory of Education: Human Constructivism and Meaningful Learning. Journal of Chemical Education, 78, 1107. https://doi.org/10.1021/ed078p1107.6

Brightwell, A., \& Grant, J. (2013). Competency-Based Training: Who Benefits? Postgraduate Medical Journal, 89, 107-110. https://doi.org/10.1136/postgradmedj-2012-130881

Brush, T. A. (1997). The Effects on Student Achievement and Attitudes When Using Integrated Learning Systems in Cooperative Pairs. Educational Technology Research and Development, 45, 51-64. https://doi.org/10.1007/BF02299612

Campos, C. (2004). Método de análise de conteúdo: ferramenta para análise de dados qualitativos na área da saúde. Revista Brasileira de Enfermagem, 57, 611-614. https://doi.org/10.1590/S0034-71672004000500019

Carraccio, C., \& Burke, A. E. (2010). Beyond Competencies and Milestones: Adding Meaning through Context. Journal of Graduate Medical Education, 2, 419-422. https://doi.org/10.4300/JGME-D-10-00127.1

Carraccio, C., Wolfsthal, S. D., Englander, R., Ferentz, K., \& Martin, C. (2002). Shifting Paradigms: From Flexner to Competencies. Academic Medicine: Journal of the Association of American Medical Colleges, 77, 361-367. https://doi.org/10.1097/00001888-200205000-00003

Cecílio, L. C. O. (2009). As necessidades de saúde como conceito estruturante na luta pela integralidade e equidade na atenção em saúde. In R. Pinheiro, \& R. A. Mattos (Eds.), Os sentidos da integralidade na atenção e no cuidado à saúde (8th ed., pp. 117-130). Rio de Janeiro: ABRASCO.

Chaturverdi, S. K. (2015). Importance of Community Medicine. https://www.linkedin.com/pulse/importance-community-medicine-dr-shyam-k-chatur vedi

Chen, H. C., van den Broek, W. E. S., \& ten Cate, O. (2015). The Case for Use of Entrustable Professional Activities in Undergraduate Medical Education. Academic Medicine, 90, 431-436. https://doi.org/10.1097/ACM.0000000000000586

Costa, A., Pedro, R., \& Magalhães, S. (2014). Medicina Geral e Familiar em Portugal. Revista Brasileira de Medicina de Família e Comunidade, 9, 295-299.

Dornan, T., Littlewood, S., Margolis, S. A., Scherpbier, A., Spencer, J., \& Ypinazar, V. (2006). How Can Experience in Clinical and Community Settings Contribute to Early Medical Education? A BEME Systematic Review. Medical Teacher, 28, 3-18. https://doi.org/10.1080/01421590500410971 
Epstein, R. M., \& Hundert, E. M. (2002). Defining and Assessing Professional Competence. (Reprinted). The Journal of the American Medical Association, 287, 226-235. https://doi.org/10.1001/jama.287.2.226

Eraut, M. (2011). Informal Learning in the Workplace: Evidence on the Real Value of Work-Based Learning (WBL). Development and Learning in Organizations, 25, 8-12. https://doi.org/10.1108/14777281111159375

Faculdade de Medicina de Marília (2014). Projeto Pedagógico do Curso de Medicina Faculdade de Medicina de Marília (46 f.). Curso de Medicina. Marília. http://www.famema.br/ensino/cursos/docs/PPC\%20Medicina.pdf

Frank, J. R., Snell, L. S., ten Cate, O., Holmboe, E. S., Carraccio, C., Swing, S. R., Harris, P., Glasgow, N. J., Campbell, C., Dath, D., Harden, R. M., Iobst, W., Long, D. M., Mungroo, R., Richardson, D. L., Sherbino, J., Silver, I., Taber, S., Martin, T. M., \& Harris, K. A. (2010). Competency-Based Medical Education: Theory to Practice. Medical Teacher, 32, 638-645. https://doi.org/10.3109/0142159X.2010.501190

Gonczi, A. (2013). Competency-Based Approaches: Linking Theory and Practice in Professional Education with Particular Reference to Health Education. Educational Philosophy and Theory, 45, 1290-1306. https://doi.org/10.1080/00131857.2013.763590

González, A. D., \& Almeida, M. J. (2010). Movimentos de mudança na formação em saúde: da medicina comunitária às diretrizes curriculares. Physis: Revista de Saúde Coletiva, 20, 551-570. https://doi.org/10.1590/S0103-73312010000200012

Gopalakrishnan, S., \& Kumar, G. (2015). Community Medicine Teaching and Evaluation: Scope of Betterment. Journal of Clinical and Diagnostic Research, 9, JE01-JE05. https://doi.org/10.7860/JCDR/2015/9873.5362

Harden, R. M. (2007). Outcome-Based Education - The Ostrich, the Peacock and the Beaver. Medical Teacher, 29, 666-671. https://doi.org/10.1080/01421590701729948

Health Canada (2002). Social Accountability-A Vision for Canadian Medical Schools. White Paper from Health Canada.

https://afmc.ca/future-of-medical-education-in-canada/medical-doctor-project/pdf/sa vision canadian medical schools en.pdf

Hodges, B. D., \& Lingard, L. (2012). Introduction. In The Question of Competence: Reconsidering Medical Education in the Twenty-First Century (pp. 1-13). New York: Cornell University Press. https://doi.org/10.7591/9780801465802-004

Holzhausen, Y., Maaz, A., Renz, A., Bosch, J., \& Peters, H. (2019). Development of Entrustable Professional Activities for Entry into Residency at the Charité Berlin. GMS Journal for Medical Education, 36, 1-16. https://doi.org/10.1186/s12909-018-1159-5

Horton, R. (2013). Public Health or Social Medicine? It Matters. The Lancet, 382, S1. https://doi.org/10.1016/S0140-6736(13)62427-7

Hunt, J. B., Bonham, C., \& Jones, L. (2011). Understanding the Goals of Service Learning and Community-Based Medical Education: A Systematic Review. Academic Medicine, 86, 246-251. https://doi.org/10.1097/ACM.0b013e3182046481

Jones, R., Higgs, R., de Angelis, C., \& Prideaux, D. (2001). Medical Education Quartet. Changing Face of Medical Curricula. The Lancet, 357, 699-703. https://doi.org/10.1016/S0140-6736(00)04134-9

Kelly, C, Coutinho, A. J., Goldgar, C., Gonsalves, W., Gutkin, C., Kellerman, R., Fetter, G., Tuggy, M., Martinez-Bianchi, V., Pauwels, J., Hinkle, B. T., Bhuyan, N., McCrory, K. E., Roett, M. A., Snellings, J., Yu, K., \& Bentley, A. (2019). Collaborating to Achieve the Optimal Family Medicine Workforce. Family Medicine, 51, 149-158.

https://doi.org/10.22454/FamMed.2019.926312 
Kishore, J. (2016). Identifying Competencies in Community Medicine: An Explorative Study in a Medical College in Delhi. International Journal of Healthcare Education \& Medical Informatics, 3, 4-10.

Kumar, R. (2005). Development of the Community Medicine Sub Specialties. Indian Journal of Community Medicine, 30, 43.

Lei $\mathrm{n}^{\circ} 8.080$ de 19 de setembro de 1990 (1990). Dispóe sobre as condições para a promoção, proteção e recuperação da saúde, a organização e o funcionamento dos serviços correspondentes e dá outras providências. Sect. 1.

Lima, V. V. (2005). Competência: Distintas abordagens e implicações na formação de profissionais de saúde. Interface (Botucatu), 9, 369-379. https://doi.org/10.1590/S1414-32832005000200012

Lynn, M. R. (1986). Determination and Quantification of Content Validity. Nursing Research, 35, 382-385. https://doi.org/10.1097/00006199-198611000-00017

Martin-Moreno, J. M., Alonso, P., Claveria, A., Gorgojo, L., \& Peiró, S. (2019). Spain: A Decentralised Health System in Constant Flux. British Medical Journal, 338, b1170.

https://doi.org/10.1136/bmj.b1170

Moreira, M. A. (2010). Aprendizagem significativa crítica. http://www.if.ufrgs.br/ moreira/apsigcritport.pdf

Muller, D., Meah, Y., Griffith, J., Palermo, A. G., Kaufman, A., Smith, K. L., \& Lieberman, S. (2010). The Role of Social and Community Service in Medical Education: The Next 100 Years. Academic Medicine, 85, 302-309.

https://doi.org/10.1097/ACM.0b013e3181c88434

Neto, G. C. C., Antunes, V. H., \& Oliveira, A. (2019). The Practice of Family and Community Medicine in Brazil: Context and Perspectives. Cadernos de Saúde Pública, 35, e00170917.

http://www.scielo.br/scielo.php?script=sci arttext\&pid=S0102-311X2019000100502\&ln $\mathrm{g}=\mathrm{en}$

Park, K. (2005). Parks Textbook of Preventive and Social Medicine (18th ed.). Jabalpur: Banarsidas Bhanot.

Peters, H., Holzhausen, Y., Boscardin, C., ten Cate, O., \& Chen, H. C. (2017). Twelve Tips for the Implementation of EPAs for Assessment and Entrustment Decisions. Medical Teacher, 39, 802-807. https://doi.org/10.1080/0142159X.2017.1331031

Raghav, P., Kumar, D., \& Bhardwaj, P. (2016). Determining Competencies for the Development of Curriculum of Community Medicine and Family Medicine for Undergraduate Medical Students. Journal of Contemporary Medical Education, 4, 54-59. https://doi.org/10.5455/jcme.20160324024006

Resolução CNE/CES n.3 de junho de 2014 (2014). Institui Diretrizes Curriculares Nacionais do Curso de Graduação em Medicina e dá outras providencias. http://portal.mec.gov.br/index.php?option=com docman\&view=download\&alias $=158$ 74-rces003-14\&category slug=junho-2014-pdf\&Itemid=30192

Santos, C. T. B., Barros, I. S., Amorim, A. C. C. L. A., Rocha, D. G., Mendonca, A. V. M., \& Sousa, M. F. (2018). Integrality in Brazilian and Venezuela: Similarities and Complementarities. Ciência \& Saúde Coletiva, 23, 1233-1240. https://doi.org/10.1590/1413-81232018234.16122016

Scarparo, A. F., Laus, A. M., Azevedo, A. L. C. S., Freitas, M. R. I., Gabriel, C. S., \& Chaves, L. D. P. (2012). Reflections on the Use of Delphi Technique in Research in Nursing. Revista Rene, 13, 242-251.

Schuwirth, L. W., \& Van der Vleuten, C. P. (2011). Programmatic Assessment: From As- 
sessment of Learning to Assessment for Learning. Medical Teacher, 33, 478-485. https://doi.org/10.3109/0142159X.2011.565828

Seyednozadi, S. M., Shahraki, M., \& Moghaddam, M. D. (2018). The Scope of Community Medicine. Razavi International Journal of Medicine, e55620. (In Press)

Sklar, D. P. (2016). Trust Is a Two-Way Street. Academic Medicine, 91, 155-158. https://doi.org/10.1097/ACM.0000000000001046

Smith, S. R. (1999). AMEE Guide No. 14: Outcome-Based Education: Part 2-Planning, Implementing and Evaluating a Competency-Based Curriculum. Medical Teacher, 21, 15-22. https://doi.org/10.1080/01421599979978

Soler, J. K., Carelli, F., Lionis, C., \& Yaman, H. (2007). The Wind of Change: After the European Definition-Orienting Undergraduate Medical Education towards General Practice/Family Medicine. The European Journal of General Practice, 13, 248-251. https://doi.org/10.1080/13814780701814986

Swanwick, T. (2014). Understanding Medical Education In Understanding Medical Education: Evidence, Theory and Practice (2nd ed., pp. 3-6). London: John Wiley \& Sons, Ltd. https://doi.org/10.1002/9781119373780.ch1

Tamblyn, R., Abrahamowicz, M., Dauphinee, D., Girard, N., Bartlett, G., Grand'Maison P., \& Brailovsky, C. (2005). Effect of a Community Oriented Problem Based Learning Curriculum on Quality of Primary Care Delivered by Graduates: Historical Cohort Comparison Study. British Medical Journal, 331, 1002.

https://doi.org/10.1136/bmj.38636.582546.7C

ten Cate, O. (2005). Entrustability of Professional Activities and Competency-Based Training. Medical Education, 39, 1176-1177.

https://doi.org/10.1111/j.1365-2929.2005.02341.x

ten Cate, O. (2006). Trust, Competence, and the Supervisor's Role in Postgraduate Training. British Medical Journal, 333, 748-751. https://doi.org/10.1136/bmj.38938.407569.94

ten Cate, O. (2013). Nuts and Bolts of Entrustable Professional Activities. Journal of Graduate Medical Education, 5, 157-158. https://doi.org/10.4300/JGME-D-12-00380.1

ten Cate, O. (2018). A Primer on Entrustable Professional Activities. Korean Journal of Medical Education, 30, 1-10. https://doi.org/10.3946/kjme.2018.76

ten Cate, O., \& Hoff, R. G. (2017). From Case-Based to Entrustment-Based Discussions. The Clinical Teacher, 14, 385-389. https://doi.org/10.1111/tct.12710

ten Cate, O., \& Scheele, F. (2007). Competency-Based Postgraduate Training: Can We Bridge the Gap between Theory and Clinical Practice? Academic Medicine, 82, 542-547. https://doi.org/10.1097/ACM.0b013e31805559c7

ten Cate, O., Graafmansa, L., Posthumusa, I., Welinkd, L., \& van Dijke, M. (2018). The EPA-Based Utrecht Undergraduate Clinical Curriculum: Development and Implementation. Medical Teacher, 40, 506-513. https://doi.org/10.1080/0142159X.2018.1435856

ten Cate, O., Snell, L., \& Carraccio, C. (2010). Medical Competence: The Interplay between Individual Ability and the Health Care Environment. Medical Teacher, 32, 669-675. https://doi.org/10.3109/0142159X.2010.500897

Touchie, C., \& ten Cate, O. (2016). The Promise, Perils, Problems and Progress of Competency-Based Medical Education. Medical Education, 50, 93-100. https://doi.org/10.1111/medu.12839

World Health Organization (1978). Report of the International Conference on Primary 
Health Care Alma Ata (79 p.). Health for All Series. Geneva, Switzerland: World Health Organization.

World Health Organization (1996). Doctors for Health: A WHO Global Strategy for Changing Medical Education and Medical Practice for Health for All. Geneva, Switzerland: World Health Organization. https://apps.who.int/iris/handle/10665/62997

World Health Organization (2000). Universities and the Health of the Disadvantaged/edited by Daniel S. Blumenthal and Charles Boelen. Geneva, Switzerland: World Health Organization. https://apps.who.int/iris/handle/10665/66711

World Health Organization (2008). The World Health Report 2008: Primary Health Care: Now more than Ever. Geneva, Switzerland: World Health Organization.

https://www.who.int/whr/2008/whr08 en.pdf

World Health Organization (2009). Teaching of Public Health in Medical Schools (87 p.). Report of the Regional Meeting Bangkok, Thailand. New Delhi: Regional Office for South-East Asia.

World Health Organization (2010). Guidelines for Preventive and Social Medicine/Community Medicine/Community Health Curriculum in the Undergraduate Medical Education (16 p.). New Delhi: Regional Office for South-East Asia.

World Health Organization (2018). Technical Series on Primary Health Care. Primary Health Care: Closing the Gap between Public Health and Primary Care through Integration (17 p.). Geneva, Switzerland: World Health Organization. 